[Hamilton, C., \& Bird, L. (1992). Impact of 1991 Policy Initiatives for Girls and Women in Education: Fibre and Fishhooks. New Zealand Annual Review of Education, 1, 59-76]

\section{Impact of 1991 Policy Initiatives for Girls and Women in Education: Fibre and Fishhooks}

\section{CAROL HAMILTON AND Lise BiRD}

$\mathrm{T}$ his paper examines the policy climate during 1991 for issues involving the education of girls and women. In many ways the year provided a more chilling wind than in previous years. The year has seen policy proposals both encouraging and discouraging for the furthering of women's education. However, as Wellingtonians are aware, winds are notoriously changeable, and our analysis attempts to incorporate some of the contradictory principles and practices that can be found within current policy proposals.

Commentators (e.g., A. Jones, 1988; Lauder, 1991) have documented a changed ethos for policy-making under the National Government. Notions of liberal humanism still popular in the fourth Labour Government have turned from an open focus on greater choice for individuals to an unfortunate reality concerned with competitive individualism in a narrow sense. In this discursive context, education is seen as a key ingredient in a philosophy which equates individual attainment at school with economic success in the context of a competitive, market-led environment (Lauder 1991, p. 4). Becoming a success in society is an individual responsibility, with educational practices geared to enhancing individual attainment. Ethnic, cultural and gender differences are subsumed by a focus on individual autonomy, which neatly avoids the vexed questions of educational advancement for Maori, working class and women students. This article will not continue the discussion over these prevailing ideologies;

\section{Carol Hamilton and Lise Bird}

instead, our paper concentrates on some of the contradictions involved in the recent policy moves which attempt to pit economic "realities" alongside a longstanding commitment to the promotion of schooling as a key method of obtaining social equality (A. Jones, McCulloch, Marshall, Smith and Smith, 1990).

Policy itself can be viewed in different frames, each with its set of key characters and lines of influence. One image of policy documents is of sets of authoritative prescriptions on educational needs and problems, to be actioned within a neutral setting (Laxon and Knight, 1989). Another view is that there are disjunctions between written, stated and enacted policy (Fulcher, 1989); this image allows for contradictions and anomalies when implementation of policy makes the leap from ministerial policy document to policy and practice within the classroom, playground and staffroom. In the "Yes, Minister" policymaking scenario, there are many different groups which influence policy at ministerial level, those in the office of the cabinet minister, the Prime Minister and other cabinet ministers, policy officials in the ministry, royal commissions and working groups, educational bodies and education unions, as well as "outside" agencies such as the Business Round Table and other organised lobbyists concerned with education. However viewed, the role of policy is a vital one, as it marks a place within the framework where there is state power to define the content and setting of educational achievement (O'Brien, 1986). Policies have real consequences for the educational life chances of women and girls who, traditionally, have been positioned as marginal to mainstream schooling concerns through the overt privileging of a male perspective (A. Jones et al., 1990).

This paper will attempt to consider not just the overall intentions of some recent policy moves, but their likely implementation within the school setting. Our analysis of contemporary policy is influenced by "deconstructive" analyses (e.g., see Knight, Smith and Sachs, 1990). By this we mean that there are likely to be opposing "discourses" at work in all policy moves, which could prove to be helpful in considering why well-thought-out policies do not always translate into the outcomes envisaged, or why poorly conceived policies may, despite the odds, provide assistance for teachers to continue to do what they do best, to teach well. In selecting the views expressed, we acknowledge the 
multiplicity of other paths left unexplored and see this presentation as a partial one, expressing thoughts about particular concepts held within the particular narrative framework of this text rather than explanations for or solutions to longstanding equity problems.

Before we consider key elements of educational policy in 1991, some historical background regarding notions of equity in New Zealand policies will be outlined. The paper will end with some thoughts on wider issues that need to be considered when planning the educational policies that are to provide key visions towards New Zealand's educational future. A key issue to be broached in the last section is the disjunction between educational and employment opportunities for women.

\section{Historical Policy Context for Gender Equity in Education and Contemporary Realities}

Historically, policy moves have concentrated on access-to-the-schooldoor types of opportunity to provide equitable educational outcomes. The 1877 Education Act provided equal access to primary schools for girls and boys. In the 1940s the Thomas Report expanded this principle to include a core curriculum for all at secondary level, where all students were to receive the "same" education. In practice these policies were seen to reinforce overtly differing educational agendas:

we think that the course of every girl...should contain studies and activities directly related to the home...e.g. clothing, laundry work"

(Department of Education, 1942, p. 5).

The Currie Report, although commenting on the differences in the educational positionings of girls and boys, did not relate the observations to actions that might rectify the problem of "making greater use of the potential skill and ability of its women" (Department of Education, 1962, p. 22).

More recently the Curriculum Review (1987) focussed on the need for radical change within the curriculum, the classroom and the school as a whole, and included a list of identifiable principles to attempt to ensure that the curriculum in every school be non-sexist, inclusive and accessible to every student. The Picot Report (Taskforce to Review Education Administration, 1988) advocated a similar idea through the equity objectives within the Charter Framework issued to schools in 1990 to be individually tailored by each school's Board of Trustees. The original plans for charters would have enabled schools to face up to equity commitments in school policies; however more and more loopholes have appeared as the charter has turned from a "contract", to an "agreement" and finally to an "undertaking" between school boards and the government.

As Alison Jones (1988) observed, a clear commitment to addressing the inequities of class, ethnicity and gender constructions of New Zealand society was lacking in all these influential policy statements, though they appeared on the surface to deal with issues of disadvantage. Were policy moves actually too far removed from the realities of the lives of women and girls to be effective in changing the conditions and assumptions within which they work? To address the issues surrounding equity within a system which continues to perpetuate sexism in education is to question the design of educational structures and to ask whom these structures benefit.

Girls' access to increasing levels of education and wider choices within the curriculum have improved this century, however. In 1987 more girls than boys left school with School Certificate, Sixth Form Certificate and Higher School Certificate; as many girls as boys (13\%) passed the University Bursary Exam; even though girls did not fare as well as boys in the Scholarship exam (1\% vs. $5 \%$ success rates, respectively; see O'Neill, 1990). Nearly half of internal university enrolments (48\%) in 1987 were from women. Although at university women are still located primarily in the arts, humanities and social science areas, women have taken significant steps into the areas of law, medicine, veterinary science and pharmacy (O'Neill, 1990). O'Neill notes that it is of concern that so few women are undertaking advanced work in engineering, business studies, agricultural technology and science. Despite the tendency towards gender-segregation in some tertiary subjects, we feel optimistic about the increasing numbers of women choosing a wider range of subject studies at the tertiary level. Nevertheless there is still the problem that these encouraging educational gains do not necessarily translate into income and employment gains for women; this is the puzzling issue for our last section. 
With this brief and rather chequered historical context for gendered education in mind, we turn to recent policy developments and examine the implications for girls and women of the four initiatives reviewed by the Minister of Education in July 1991. Here we refer to education as a much broader concept than particular training in preparation for specific jobs.

\section{The Four Key Policy Elements}

The Minister of Education outlined four elements central to the new policy direction of the National Government in the National Education Policy statement (Smith, 1991a): the Achievement Initiative as part of the Draft National Curriculum, the National Certificate, the Parents as First Teachers Programme, and Study Right. We will briefly examine each initiative and consider some implications for greater educational equity for girls and women.

\section{1) The Draft National Curriculum and the Achievement Initiatives}

Central to the idea of the revamped national curriculum (DNC) (Learning Media, 1991) is the "Achievement Initiative". Current proposals are for a coordinated and coherent curriculum for schools covering a set of main principles, essential learning areas, essential skills and national objectives and assessment guidelines. Because of the complexity of these issues, we will make brief comments about some of their implications for the education of girls and women.

Contained in the section on "Principles" is the expectation that equal educational opportunities will be provided for all students; i.e., that the curriculum should:

recognise, respect and respond to the educational needs, experiences, achievements and pers pectives of both female and male students, and of all races and ethnic groups.

and that:

programmes are non-sexist, non-racist and nondiscriminatory (Learning Media, 1991, p. 6)

This is a particularly welcome inclusion for girls and women who have experienced high degrees of alienation from the educative process as a direct result of their gender, class and ethnic background. However, the document does not include any guidance to ensure that equal educational opportunities and non-sexist education will be encouraged. Further, the lack of a section on implementation to provide support for schools as they develop the spirit of the Principle may leave the idea without the hope of a strong practical base.

Following the changed mandate for the ERO to review equity requirements (Ministry of Education, 1991a), schools were left without clear directions to remove barriers to achievement to ensure that students of all backgrounds could fulfil their potential. In some respects, schools are in the best on-site position to see the principles are carried out, but issues surrounding notions of equality are highly contentious and problems can arise when they are to be interpreted within individual and community understandings.

The DNC gives a fairly traditional listing of seven curriculum ("Essential Learning") content areas: language, mathematics, science and environment, technology, social sciences, arts, physical and personal development (in that order). The content of these areas awaits completion ${ }^{2}$ as does concrete analysis of what this curricular programme may do to advantage/disadvantage the education of women and girls. A positive move is that the four subjects basic to the Curriculum (English, Science, Mathematics and Technology) will be compulsory for all students to Form 5, which could provide an incentive for girls to participate more fully in areas in which traditionally they have not been well represented. Such compulsory subject areas may help keep girls' options open for senior secondary school and tertiary education, to enhance their future employment opportunities. On the other hand, there is still a "hidden curriculum" which keeps learning experiences of girls and boys worlds apart. A negative implication of the focus on separate, examinable Form 5 subjects is that it shores up the authority of discrete disciplines in the curriculum rather than opening up possibilities for links across curriculum areas. For example, in the area of chemistry the learning of girls (and of boys from some ethnic and social backgrounds) may be enhanced if more links are made to topics closer to everyday experience, as might be provided in some biology or geography lessons. 
A less sanguine prospect is that the DNC fails to address the vital importance to any schooling experience of curriculum enactment by teachers and students in their classrooms. Neglecting this aspect creates in the document an overlying air of process-" neutrality" which sidesteps well-known problems concerning gender, class and ethnic inequities in the classroom (e.g., A. Jones, 1991). Since educational opportunity does not always translate into educational outcomes, the greater access for girls to the curriculum may not be enough to ensure equitable goals.

The DNC also discusses assessment targets in a section on "Achievement Objectives and Levels". Explicit attainment objectives are designed to express what has been learned at various stages in the learning process, a useful clarification of learning goals at school; yet the proposal leans towards the prescriptive, concentrating on a core curriculum and arranged sets of levels through which all students should pass in attaining particular goals. There is an assumption that the same sequence of learning tasks describes the optimum learning trajectory for everyone and that the wider ethos and value of the individual school is of peripheral interest in the process of individual learning - an assumption which we question.

As the NZEI (1991) outlines in its response to the document, having too great a degree of specificity in assessment targets could create difficulties. The NZEI suggests that objectives be broad enough to allow schools flexibility to plan their own programmes while being specific enough to enable teachers to decide on the particular needs of each student. Flexibility is vital to the needs of both girls and boys in the education setting, as all students' assessment needs do not necessarily fit into predictable steps. In particular, girls need to be able to capitalise more consistently on the talents and interests they bring into the classroom. The context in which the learning takes place needs to be emphasised, to ensure that assessment objectives do not perpetuate notions of individual intellectual deficiency rectifiable through greater technical precision in describing learning outcomes. There are encouraging moves within the draft Mathematics curriculum which looks at learning and assessment in maths in broad-based ways which could be more inclusive for a greater variety of students.

An important policy initiative from the Ministry of Education which could make a difference to the implementation of the national curriculum is the "Barriers to the Participation and Achievement of Girls and Women in Education and Training", currently underway. ${ }^{3}$ Its brief, to assess the current participation of women in education and vocational training and to assess priority areas within current policy objectives for inclusion in final reports, is an exciting development. It will be interesting to see how recommendations from this project are to be targeted and implemented as there are contradictions involved in the DNC's stated goal to encourage "healthy competition" and "how to cope with not always winning, and how to train harder for the next time" (Learning Media, 1989, p. 15). There is hope for greater equity for girls and women of different cultural groups if there is greater emphasis on a wide variety of learning styles, across a great range of curriculum materials and types of assessment, rather than a narrowing of focus onto more traditional educational practices which have historically disadvantaged girls. We think it is important to add, however, that a sad event in 1991 was the disbanding of the Women's Advisory Committee on Education (WACE) on 30 July. WACE was an independently established committee which considered a range of political analyses for their impact on girls and women. It is not clear how the breadth of expertise and wider vision represented by WACE will be replicated in other more ad hoc structures currently being considered.

\section{2) The National Certificate}

An interesting development in the qualifications area is the new National Certificate, a comprehensive academic and vocational certificate which will subsume a number of earlier qualifications. This certificate will for example provide learning in vocationally related topics to be studied in senior secondary school, polytechnics, business firms or other private providers. The aim is to "reduce artificial distinctions between academic and vocational education" (Smith, 1991a). Currently, this initiative has no fixed date for completion (Ministry of Education, 1991b, p. 18).

Policy commitment to vocationally related courses is a welcome move for girls, as women experience difficulty entering and remaining in trades areas. In March 1986, there were 27,730 apprenticeship contracts in force, with only $9.7 \%$ of these contracts held by women. 
Most female apprentices held contracts in hairdressing. Difficulties experienced by women apprentices include poor working conditions, lack of family support, difficult employers, and unreasonably heavy and tedious work (Horsfield and Rogers, 1988). It is hoped that forthcoming policies will address the serious imbalance these figures reveal.

The inclusion of compulsory core subjects to form 5 in the national curriculum will link in with the emerging National Certificate structures, as School Certificate may become a less mainstream qualification $_{1}$ targeted at a select group of students. There could be dangers for gender equity in the possibility of gender-specific paths developing through the modules or segments of the National Certificate, if girls tend to avoid certain mathematics, science, technology and trade subjects. There is now some provision for recognition of women's traditional work as "prior experience" in the certificate, but there is also some danger that this is merely tinkering with the hurdles facing women's achievement, instead of providing resources for women to expand their skills. It could be seen as a cheap way to allow women to run further towards the next hurdle, without giving them the skills to get further, either by bringing the hurdle down to size or changing its shape to fit the skills of more women. We hope the Barriers to Achievement initiative will have the scope to address some of these issues.

\section{3) Parents as First Teachers}

As outlined in Meade and Dalli's chapter in this volume, in 1991 the Minister of Education set as a new policy initiative a trial of research which would be an extension of the New Parents as Teachers project commissioned by the Missouri State Department of Education in the early 1980s (Meyerhoff and White, 1986). Podmore and Bird (1991, p. 64) have pointed out that the research of the Missouri group ran counter to the zeitgeist of research in early childhood at the time, which tended to focus more on the quality of interaction between caregivers (both parents and professionals) in early childhood settings, rather than upon at-home intervention designs (which had been more popular in the 1970s). In the USA research has moved away from the "Head Start" era of intervention in parent training, with its lack of attention to possible cultural insensitivity of "expert" researchers working with families of non-dominant ethnic groups. As Kennedy (1991) and Dalli (in press) have noted, the early childhood landscape in this country has always had a number of complex features. In addition, there is a great variety of extended family structures. These complexities make it crucial that new initiatives for parental support are introduced within a context sensitive to cultural diversity and cognisant of the range of early childhood services available.

In a speech to the New Zealand Association for Research in Education in November, the Minister (Smith, 1991b) implied that poor educational achievement of some groups in society (presumably referring to students from lower socio-economic or Maori families) would benefit from more skilled parenting, such as the Parents as First Teachers initiative might provide. This was of course the philosophy behind the "Head Start" programmes in the USA, in an era of looking for causal factors in families deemed to be deficient in communication and stimulation of their children. A likely consequence of the argument is that mothers traditionally at home working in domestic and childcare areas need to be better at their job as unpaid early childhood teachers. The British writer Walkerdine (1989) has rather humorously pointed out a trend in middle-class childrearing towards the perfect mother who turns every waking moment of a child's day into an educational experience. Given the increasing likelihood of mothers having even greater difficulty in the current economic climate of furthering their own education, increasing the burden on women at home seems a rather cruel, if perhaps unforeseen, potential outcome of this policy. This issue is referred to again in the next section.

\section{4) Study Right}

There will be reduced tertiary study fees for students in their first three years of full time study by age 22 . It is difficult to foresee the full impact of this policy for girls and women, given that its effects are likely to be pervasive. For example, in families with limited resources there may be some tendency to favour sons if only one child can be financed to attend tertiary study. It is difficult to predict exactly how this policy will be effected in practice, but there appear to be major fishhooks for women.

The training of teachers is likely to be greatly affected by Study Right changes. The increasing flow of adults, most of whom are women, 
taking up teacher training after age 22, is likely to be reduced to a trickle as the students who can afford to obtain teacher training become the young students eligible for Study Right. Junior teachers with the least experience are likely to be in greater demand as schools are pressured to hire the least expensive staff for relieving and full-time positions. The implications of these changes are yet to be worked through, but it is likely that there will be a decrease in the incomes of teachers, particularly for younger and relieving teachers, those most likely to be women.

The greatest impact overall of Study Right may indeed be on women who return to study as adults. Many young women tend to get involved with family responsibilities early in adulthood, and such women are unlikely to have economic and social support for further study until their children have grown older, when such mothers will be over age 22. Returning women students are more likely to be lower income earners than returning male students, especially if they have been at home in domestic and childcare work. Quite a number of recent policy changes will probably have considerable consequences for women's financial positions. For example, the reduction in funding for Special Education services will probably have its greatest effect on women who carry out much of the childcare work for children with special needs. Changes in the Domestic Purposes Benefit are also likely to have their greatest effect on young mothers, who may be even less likely in future to find the financial resources for tertiary study in their adult lives. Similarly, changes in health charges, housing corporation rents, and childcare subsidies are likely to hit women hardest, especially women raising children alone. All these interconnected policy changes have a cumulative effect on education of women for the future, which bodes ill for one of the most fastest growing sectors (i.e., returning women) for continuing education.

\section{Endnotes}

There are a number of positive moves in education policy for girls and women in 1991, a recipe which adds plenty of wholesome fibre to the mixture of policy proposals. An encouraging move is the potentially greater flexibility in the National Certificate for creating a wide range of paths through advanced qualifications. The introduction of compulsory science and mathematics subjects at Form 5 is also a forward move for girls' education, since greater exposure to these subjects may widen girls' employment choices. However, the curriculum of these subjects need to be broadened to ensure that the subjects are relevant and facilitating for girls (and boys) from a wide variety of cultural backgrounds. There are some exciting developments in the mathematics and science areas that could be of great benefit to girls in widening the traditional curriculum and bringing in a greater variety of assessment practices at primary and secondary school to be sure that every student's learning and achievement is catered for within the new guidelines of the achievement initiatives. However, the possibilities for enhancing learning by making greater links across curriculum areas has been an opportunity missed in the current policy moves.

The picture for women students has less potential for optimism, which puts something of a damper on the potential promised in the new curriculum, assessment and qualification reforms. Women returning to study in their adult years are likely to be greatly disadvantaged on a number of counts which we have outlined. As an example, in the present difficult economic climate, there seems to be little potential for returning women students on low incomes to secure loans for the purposes of furthering their studies. If returning women do manage to secure a qualification after extra years of part-time study, they will be entering the job market disadvantaged by their age. Of course, a small proportion of women will do well under such circumstances, despite the odds. We note that there are key figures seeded here and there in ministries and government departments who gained their qualifications as returning women students, and who have made a significant contribution to government policy creation and implementation which is sensitive to gender and cultural equity concerns. However, for most women the path to "second chance" education in adult life will be an even rockier road in future. The emphasis on traditional family values, which could be seen as an underlying tenet of the Parents as First Teachers initiative, will be another contextual factor unlikely to create a social environment helpful to women who want to further their education.

Similarly, back in the schoolroom, girls continue to face particular disadvantages. An Australian review of literature (J. Jones, 1990) found 
that girls participated poorly in certain school subjects, lacked self esteem and confidence in their own ability, and suffered educationally in certain coeducational settings. Researchers have pointed to:

the language of sexual abuse, physical harassment, and male colonisation of the space of the school (Arnot, 1991, p. 11)

which forms part of the reality of everyday life of most schoolgirls in coeducational schools (cf. Bird, 1992; Rout, 1992). The draft National Curriculum guidelines work from within the baseline presumption that equity in matters of schooling will equip girls for success in the workplace. If job success is a key "outcome measure" for the likely success of current policy moves in education, what are the links between education and employment for girls?

Recently Mickelson (1989) has observed that female students continue to strive and achieve well academically despite a hostile economic climate. Writing about the USA, Mickelson points out that more women than men graduate from high school, receive bachelor's degrees, and enrol in post-graduate, masters programmes. Yet women are likely to earn only two-thirds to three-quarters as much as men. In her traditional sociological analysis of rational reasons for people's behaviour, Mickelson asks, in a rather tongue-in-cheek fashion, whether women are just less logical than men in putting their energies into furthering their educations when the financial rewards are not likely to be there for them.

In their description of structural inequalities in the working world, which has many resonances with work on girls and schooling, Reskin and Roos (1990) carried out research on areas of sex desegregation in particular occupations. They found that women's progress in employment occupationally and economically, relative to men, was disappointing. Rather than genuine progress being made towards occupational equity with male co-workers of equivalent experience, nominal desegregation or ghettoisation was the outcome in the occupations studied. Women were still concentrated in lower paying, less desirable and dead-end jobs, although they had made more headway in entering male occupations since the 1970s than in any previous decade. As women gained access to traditionally male occupations, the occupations had lost much of their attraction to men and were becoming less advantageous to women as well.

In addition Reskin and Roos (1990) found that gender-integration reflected sometimes only a temporary stage in a longer process of resegregation, where an entire occupational specialty switched from a predominantly male to a predominantly female labour force. Men abandoned specialities within occupations because they experienced a decline in their earning capacity, a decline in job autonomy through fewer entrepreneurial opportunities, a reduced availability of full-time work and a shift in content away from masculine to more feminine tasks. Reskin and Roos also confirmed that male opposition remained an effective force for exclusion. Affirmative action initiatives did result in employers specifically recruiting women to fill job openings, but these positions were often jobs with little opportunity for upward mobility (e.g., public relations specialists) where they were not a competitive threat to highly placed men. Women's inroads into the occupations in the study resulted in small earnings gains relative to the average male worker, though the women studied did improve their earnings relative to the average woman worker. Changes in the labour force tended to point to a perpetuation of segregation by gender; such ghettoisation represents very limited progress for women.

Contemporary educational policies tend to make invisible the fact that the working world is radically different for women and men. There is also the problem that women's experiences of working life are materially different, depending on each woman's relative social positioning in terms of ethnic group and social class. Poverty is an overwhelmingly female problem (see Bunkle, 1990).

Education policy in 1991 has taken only a few halting steps beyond the liberal democratic idea of equality of opportunity for all citizens, which by definition glibly includes all women. As such, policies in 1991 have failed to address structural gender inequalities thereby maintaining the gap between policy goals and their outcomes. ${ }^{4}$ Indeed, there is scepticism about whether the existing structures of schooling could ever accommodate genuine gender equality in schools (A. Jones et al., 1990). It is possible that we could end with greater feminisation of the schooling process in future, creating similarities between the world of education and work (cf., Reskin and Roos, 1990). For example, boys 
could have their vocational education supplied by private enterprise, while girls stay on at school, getting further credits for their National Certificate, in traditional "girl friendly" subject areas, which would have less resource support in terms of facilities, teachers and equipment.

Another gloomy scenario is that only middle class pakeha women may be able to take advantage of the flexibility that the new qualifications structures and Study Right might open. With the current greater emphasis on personal financial resources in getting access to further education, the outlook for Maori and working class women, who have been disadvantaged for so long, historically, in this country seems particularly bleak. Smith (1991a) perceives that there are identifiable groups in the community which have already suffered substantial disadvantage in educational matters, disadvantages the currently proposed policy reforms are designed to address. A useful addition to this analysis would be a greater awareness of the context surrounding girls' learning, since current indications are that women will not necessarily increase their job success even if they continue to achieve in education. Blanket provisions aimed at equitable outcomes cannot address the more intransigent issues of inequities in women's experiences, due to their different positionings in terms of ethnic group and social class.

Whatever the plausibility of these scenarios the problem now is not that girls and women are disadvantaged because of their absence from the classroom, a problem that the opening of doors heretofore shut will necessarily rectify; but that the rooms into which girls and women are being invited may not be suitable, may not be comfortable places in which to work, or may not provide girls with the post-schooling benefits implied in the policy initiatives.

Notes

1 We would especially like to thank Sandi Aiken and Lynne Middleton of the NZEI for helpful comments on an earlier draft of this article. We also found very helpful an unpublished paper by Robyn Baker and Helen Leahy (1991).

2 The Ministry of Education Policy Works Programme (Ministry of Education, 1991b), is as follows: (1) The Achievement Initiative for English/Language will be developed in 1991-1992, and phased in and completed in 1993/1994. The proposals for the Achievement Initiative for Science will be completed in 1992. The proposals for the Achievement Initiative for Mathematics are under discussion in early 1992. The Achievement Initiative for Technology is planned for discussion in 1992.

3 Barriers to Participation and Achievement for Girls and Women in Education and Training. The completion date was for December 1991, though the work is still progressing.

4 Vanderbosch and Swoboda (1984) have pointed out that liberal humanist perspectives have particular masculinist assumptions.

\section{References}

Arnot, M. Feminism, Education and the New Right, Paper presented to the AERA, Chicago, 1991, April.

Baker, R. \& Leahy, H. Beyond Access: Curriculum Development and the Position of Girls. Unpublished M.Ed. paper, Victoria University, 1991.

Bird, L. Girls taking positions of authority at primary school. In S. Middleton and A. Jones (Eds.), Women and Education in Aotearoa. Vol. 2. Wellington: Bridget Williams Books, 1992.

Bunkle, P. Across the Counter - The Lives of the Working Poor in New Zealand 1990: Report of the Second New Zealand Sweating Commission. Wellington: The Commission, 1990.

Committee to Review the Curriculum for Schools The Curriculum Review, Wellington: Government Printer, 1987.

Dalli, C. Policy scripts for children's lives. New Zealand Journal of Educational Studies, in press.

Department of Education The Post Primary School Curriculum, Wellington: Department of Education, 1942 (Currie Report).

Department of Education Report of the Commission on Education in New Zealand, Wellington: Government Printer, 1962 (Thomas Report).

Fulcher, G. Disability Policies? A Comprehensive Approach to Educational Policy. London: Falmer Press, 1989.

Horsfield, A. and Rogers, A. Women in the Economy: A Research Report on the Economic Position of Women in New Zealand. Wellington: Ministry of Women's Affairs, 1988.

Jones, A. Education Policy And The Move To The New Right In New Zealand, Women's Studies Association Conference Papers, 1988.

Jones, A. "At School I've Got a Chance" - Culture/Privilege: Pacific Islands and Pakeha Girls at School. Palmerston North: Dunmore Press, 1991. 
Jones, A., McCulloch, G., Marshall, J., Smith, G. H. \& Smith, L. T. Myths and Realities: Schooling in New Zealand, Palmerston North: Dunmore Press, 1990.

Jones, Jennifer. Outcomes of Girls Schooling: Unravelling some Social Differences, Australian Journal of Education, 34 (2), 1990, 153-167.

Kennedy, P. State intervention versus parent power. Paper presented at the seminar, Parents as Partners; Parents as Educators. Wellington: NZCER, 1991, March.

Knight, J., Smith, R. \& Sachs, J. Deconstructing hegemony: Multicultural policy and a populist response. In S. Ball (Ed.), Foucault and Education: Disciplines and Knowledge, London: Routledge, 1990.

Lauder, H. The Lauder Report: Tomorrow's Education, Tomorrow's Economy, Victoria University of Wellington, 1991.

Laxon, J. and Knight, J. Deconstructing "womanhood": "Gender equity" in Queensland Education Policy. Paper presented to the Victoria University Education Department, 1989.

Learning Media. The National Curriculum of New Zealand: A Discussion Document. Wellington: Ministry of Education, 1989.

Meyerhoff, M. K. and White, B. L. Making the grade as parents. Psychology Today, 1986, September, pp. 38-45.

Mickelson, R. A. Why Does Jane Read and Write So Well? The Anomaly of Women's Achievement. Sociology of Education, 62, 1989, pp. 47-63.

Ministry of Education The Education Gazette, Wellington: Government Printer, 1991a, 1 August.

Ministry of Education Policy Works Programme, January 1991 to December 1993, Wellington: Government Printer, 1991b.

NZEI NZEI Response to the National Curriculum Discussion Document, Wellington: NZEI, 1991.

O'Brien, M. Feminism and the politics of education. Interchange, 17 (2), 1986, 91-105.

O'Neill, A-M. "The equal opportunity myth: Women in New Zealand Educational Institutions" in Olsson, S. (Ed.) The Gender Factor: Women in New Zealand Organisations. Palmerston North: Dunmore, 1992.

Podmore, V.N. \& Bird, L. Parenting and Children's Development in New Zealand: Research on Childrearing, Parental Beliefs and Parent-Child Interaction. NZARE "State of the Art" Monograph No. 3. Palmerston North: NZARE, 1991.

Reskin, B. \& Roos, P. Job Queues, Gender Queues. Philadelphia: Temple University Press, 1990.
76 Carol Hamilton and Lise Bird

Rout, B. Being "staunch": boys hassling girls. In S. Middleton and A. Jones (Eds.), Women and Education in Aotearoa. Vol. 2. Wellington: Bridget Williams Books, 1992.

Smith, The Hon. Lockwood Education Policy: Investing in People, Our Greatest Asset, Wellington: Government Printer, 1991a.

Smith, The Hon. Lockwood. Speech Notes. Paper presented to the New Zealand Association for Research in Education, Knox College, Dunedin, 1991b, November.

Taskforce to Review Education Administration. Administering for Excellence. Wellington: Government Printer, 1988 (Picot Report).

Vanderbosch J. \& Swoboda M. Anomalies and paradigms: Feminist criticism and general education. Liberal Education, 70 (3), 1984, 223-227.

Walkerdine, V. Democracy in the Kitchen, London: Virago, 1989.

\section{The authors}

Carol Hamilton is a trained primary teacher who has taught at both primary and secondary levels. She is currently writing a thesis which is a critique of current educational policies in New Zealand.

Lise Bird is a Senior Lecturer in the Education Department at Victoria University of Wellington. She teaches courses on gender and education from feminist perspectives. Her research is in the area of empowering girls in practices at schools. 